\title{
CMEARTICLE
}

\section{Managing tooth pain in general practice}

Sky Wei Chee $\underline{K o h}^{1}$, MBChB, Chun Fai $\underline{L i}^{2}$, BDS, John Ser Pheng $\underline{L o h}{ }^{2}$, MDS, MBBS, Mun Loke Wong ${ }^{2}$, BDS, MSc, Victor Weng Keong $\underline{L O h}^{1}$, MCFP, MHPE

Mr Tan, a 48-year-old banker with no significant past medical history, visited your clinic with the complaint of severe right-sided tooth pain that radiated to the right temporal region of the head. The pain was excruciating and had affected his concentration at work. The overthe-counter paracetamol he had taken did not seem to relieve the pain and Mr Tan felt that it could not just be a simple toothache. He asked you to prescribe some antibiotics to treat what he believed was a dental infection.

\section{WHAT IS TOOTH PAIN?}

Tooth pain, which is often known as toothache, refers to the symptom of pain arising from the tooth (or teeth).

\section{HOW COMMON IS THIS IN MY PRACTICE?}

Dental caries (Fig. 1) is a common dental condition. Globally, up to $35 \%$ of people have untreated dental caries, ${ }^{(1)}$ and an estimated $32.4 \%$ of the Singapore population will experience pain from symptomatic dental caries in their lifetime. ${ }^{(2)}$ Locally, oral disease is ranked 16th in terms of years lost to disability and has been an important cause of functional and social impairment. ${ }^{(2)}$ Other common causes of tooth pain include periodontal disease and dental trauma. Patients often seek the opinion of their family doctors for their tooth pain.

\section{HOW IS THIS RELEVANT TO MY PRACTICE?}

Primary care physicians are well placed to help patients presenting with tooth pain at their clinics for a number of reasons: they provide opportunistic general and dental health promotion advice, manage a number of causes of orofacial pain, and diagnose systemic conditions that have oral presentations. Primary care physicians need to keep in mind how chronic conditions and lifestyle factors may relate to oral conditions. For instance, patients with poorly controlled diabetes mellitus have a threefold increased risk of developing periodontitis (Fig. 2). ${ }^{(3)}$ Smoking and alcohol consumption increase the risk of oropharyngeal cancers, and patients with osteoporosis on long-term bisphosphonates or RANKL (receptor activator of nuclear factor kappa-B ligand) inhibitors such as denosumab are at increased risk of medicationrelated osteonecrosis of the jaw. ${ }^{(4)}$

In turn, oral conditions may be associated with chronic conditions. For example, poor oral hygiene increases the risk of infective endocarditis-related bacteraemia after tooth brushing by three- to fourfold. ${ }^{(5)}$ In addition, conditions such as oral candidiasis may point to the underlying immunosuppression seen in HIV infection. ${ }^{(6)}$ This bidirectional relationship underscores the pivotal role that primary care physicians play in the prompt diagnosis, investigation and management of patients with oral conditions.

\section{WHAT CAN I DO IN MY PRACTICE? Clinical history and examination}

Many oral conditions may mimic tooth pain and it is important to delineate the different causes with history-taking and examination. We suggest the following:

- Identify the source of pain by taking a comprehensive pain history.

- $\quad$ Check for fever and signs of spread (e.g. local swelling or cervical lymphadenopathy).

- Examine the oral cavity (i.e. tonsils, palate, tongue and ulcers).

- Examine the dentition and gums, specifically looking out for dental caries (Fig. 1), gingival oedema and abscesses, loose or broken fillings, ill-fitting dentures, and tooth mobility.

- $\quad$ Screen for other possible causes of non-odontogenic pain (e.g. temporomandibular joint, eyes, sinuses, ears, and the parotid and submandibular glands).

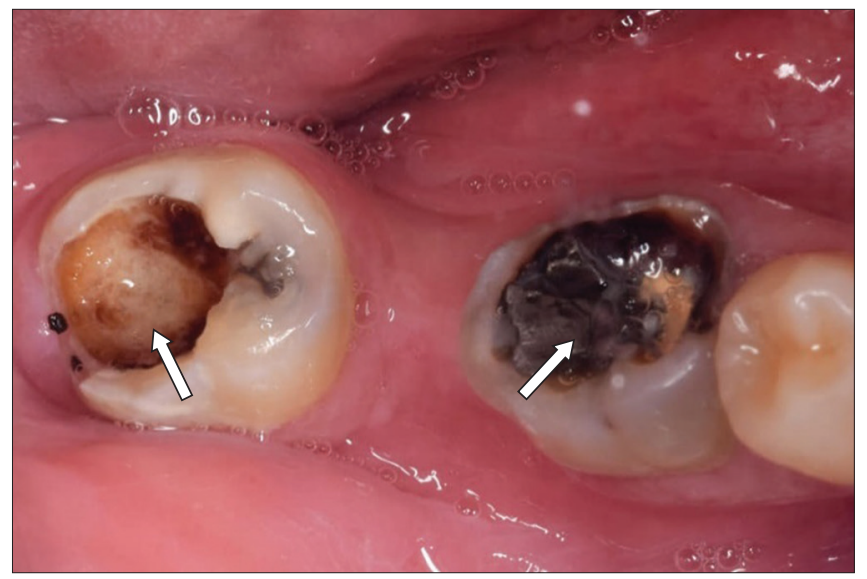

Fig. 1 Photograph shows dental caries in a patient, with visible tooth decay (arrows) 
Table I. Causes of odontogenic pain.

\begin{tabular}{|c|c|c|}
\hline Diagnosis & Findings & Assessment and treatment \\
\hline Dentine hypersensitivity & $\begin{array}{l}\text { - Discomfort on cold stimulus that resolves almost } \\
\text { immediately after stimulus removal } \\
\text { - Tooth will likely have receding gum lines and } \\
\text { exposed dentine }\end{array}$ & $\begin{array}{l}\text { - Advice to reduce acidity in diet } \\
\text { - Desensitising toothpaste }\end{array}$ \\
\hline $\begin{array}{l}\text { Periodontal disease (infection } \\
\text { of the supporting structure of } \\
\text { the tooth, including gingiva and } \\
\text { alveolar bone) }\end{array}$ & $\begin{array}{l}\text { - Swollen and oedematous gum } \\
\text { - Tooth may be shaky and have receding gum line }\end{array}$ & $\begin{array}{l}\text { - Analgesia } \\
\text { - Antimicrobial mouthwash } \\
\text { - Referral to dentist for periodontal therapy or } \\
\text { extraction }\end{array}$ \\
\hline $\begin{array}{l}\text { Pericoronitis (impacted wisdom } \\
\text { tooth) }{ }^{(7)}\end{array}$ & $\begin{array}{l}\text { - Inflamed periodontal attachment around } \\
\text { impacted wisdom tooth } \\
\text { - May be accompanied by trismus }\end{array}$ & $\begin{array}{l}\text { - Analgesia } \\
\text { - Antimicrobial mouthwash } \\
\text { - Referral to dentist for removal of wisdom tooth }\end{array}$ \\
\hline $\begin{array}{l}\text { Endodontic disease (infection } \\
\text { of the root canal system of the } \\
\text { tooth) }\end{array}$ & $\begin{array}{l}\text { - Often the result of dental caries (Fig. 1) } \\
\text { - Pain and tenderness on percussion and palpation } \\
\text { of tooth } \\
\text { - Can have sharp lingering pain on cold stimulus, } \\
\text { often more than } 30 \text { seconds after stimulus } \\
\text { removal } \\
\text { - May have local swelling, purulent discharge } \\
\text { and/or systemic symptoms: fever, malaise and } \\
\text { lymphadenopathy (late presentation) }\end{array}$ & $\begin{array}{l}\text { - Analgesia } \\
\text { - Immediate referral for extraction with incision } \\
\text { and drainage, or root canal treatment } \\
\text { - May require admission for intravenous } \\
\text { antibiotics in severe cases (e.g. Ludwig's angina } \\
\text { resulting in airway compromise) }\end{array}$ \\
\hline $\begin{array}{l}\text { Medication-related osteonecrosis } \\
\text { of the jaw }{ }^{(4,9)}\end{array}$ & $\begin{array}{l}\text { - Current or previous treatment with antiresorptive } \\
\text { or antiangiogenic agents (e.g. bisphosphonates, } \\
\text { denosumab, bevacizumab) } \\
\text { - Absence of prior radiation or metastatic disease to } \\
\text { the jaw } \\
\text { - Exposed bone or bone fistula }>8 \mathrm{wk}\end{array}$ & $\begin{array}{l}\text { - Stop offending agent and review need for } \\
\text { continued treatment } \\
\text { - Consider antimicrobial mouthwash and close } \\
\text { follow-up } \\
\text { - Prompt referral for symptoms: pain, oedema or } \\
\text { erythema - may require surgical debridement }\end{array}$ \\
\hline
\end{tabular}

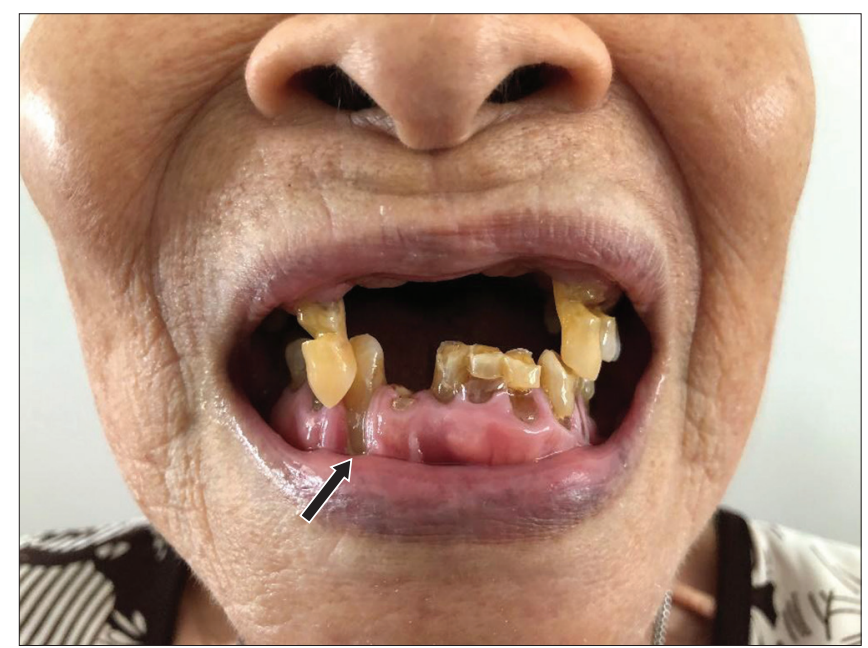

Fig. 2 Photograph shows a patient with periodontitis characterised by gingival recession (arrow).

\section{Diagnosis and management}

The key decision point in managing patients with tooth pain is determining whether the pain is odontogenic or non-odontogenic in origin.

\section{Odontogenic pain}

Odontogenic pain, or pain arising from the tooth, may be recognised by the following characteristics: it is often localised to the tooth, has an excruciating and acute onset, and is exquisitely sensitive to hot or cold stimulus. It may be aggravated by biting or chewing, is typically associated with dental caries or dental trauma (look for chipped surfaces or lacerated gingival tissues) and may sometimes be due to periodontal disease. In general, patients with odontogenic pain should be referred to a dentist. A summary of the common causes of odontogenic pain seen in primary care are listed in Table I.

\section{Non-odontogenic pain}

Non-odontogenic pain refers to tooth pain that does not arise from the tooth. As there are many non-odontogenic causes of tooth pain, an exhaustive list is beyond the scope of this article and more comprehensive resources are recommended.(10,11) Nonetheless, the primary care physician needs to consider the following red flags in patients who seem to present with tooth pain: (a) acute coronary syndrome - presenting with radiation of pain to the jaw; (b) peritonsillar abscess - presenting with odynophagia, trismus and hoarseness; and (c) temporal arteritis - presenting with temporal headache, visual defects, jaw claudication, or neck and shoulder stiffness.

Common non-odontogenic causes of orofacial pain seen in primary care are highlighted in Table II. Most of these may be easily diagnosed and managed in primary care.

\section{Prescribing analgesia for odontogenic pain}

Paracetamol and short-acting non-steroidal anti-inflammatory drugs (NSAIDs) form the mainstay of pain management. Ibuprofen has been shown to have good efficacy and safety, and 
Table II. Causes of non-odontogenic orofacial pain.

\begin{tabular}{|c|c|c|}
\hline Diagnosis & Findings & Assessment and treatment \\
\hline Pharyngotonsillitis ${ }^{(12)}$ & $\begin{array}{l}\text { - Odynophagia with inflamed oropharynx } \\
\text { - May have fever and cervical lymphadenopathy }\end{array}$ & $\begin{array}{l}\text { - Analgesia, lozenges and mouthwash } \\
\text { - Antibiotics if indicated (CENTOR criteria) }\end{array}$ \\
\hline Bacterial sinusitis ${ }^{(13)}$ & $\begin{array}{l}\text { - Nasal obstruction with purulent discharge } \\
\text { - Facial pain or fullness for }>10 \text { days } \\
\text { - Fever, malaise, headache and anosmia }\end{array}$ & $\begin{array}{l}\text { - Analgesia, intranasal steroids, saline irrigation } \\
\text { - Antibiotics if indicated (1st line: amoxicillin } \pm \text { clavulanate, } \\
\text { 2nd line: doxycycline or levofloxacin) }\end{array}$ \\
\hline Apthous ulcer & $\begin{array}{l}\text { - Occurs on soft tissue, well-defined border with a } \\
\text { yellowish centre } \\
\text { - Surrounded by an erythematous halo and some } \\
\text { oedema }\end{array}$ & $\begin{array}{l}\text { - Oral hygiene } \\
\text { • Topical lidocaine/triamcinolone preparations }\end{array}$ \\
\hline Migraine $^{(14,15,16)}$ & $\begin{array}{l}\text { - Recurrent unilateral, pulsating headaches } \\
\text { - Worsened by physical activity } \\
\text { - May be associated with nausea or vomiting, } \\
\text { photophobia and phonophobia }\end{array}$ & $\begin{array}{l}\text { - Analgesia } \\
\text { - Triptans if severe or refractory } \\
\text { - Consider prophylaxis if recurrent }\end{array}$ \\
\hline $\begin{array}{l}\text { Temporomandibular joint } \\
\text { dysfunction }^{(17,18)}\end{array}$ & $\begin{array}{l}\text { - Tenderness over the temporomandibular joint and } \\
\text { muscles of mastication } \\
\text { - Worsened by jaw movement } \\
\text { - May be associated with headache and jaw crepitus }\end{array}$ & $\begin{array}{l}\text { - Advice on sleep posture, avoiding triggers (e.g. nail } \\
\text { biting) } \\
\text { - Analgesia } \\
\text { - Consider referral to dentist for bruxism (occlusal } \\
\text { splints) or oromaxillofacial surgery if refractory }\end{array}$ \\
\hline Trigeminal neuralgia ${ }^{(19)}$ & $\begin{array}{l}\text { - Recurrent unilateral shooting hemifacial } \\
\text { pain (trigeminal area) } \\
\text { - Precipitated by innocuous stimuli } \\
\text { - Exclude herpes zoster and multiple sclerosis }\end{array}$ & $\begin{array}{l}\text { - Carbamazepine } \\
\text { - Consider prophylaxis if persistent } \\
\text { - Neurology referral if refractory }\end{array}$ \\
\hline
\end{tabular}

is cost-effective. ${ }^{(20)}$ Opioid alternatives such as tramadol, which carries the risk of dependency and other side effects, may be carefully considered if required. Antimicrobial mouthwash can be useful for osteonecrosis of the jaw and pericoronitis (i.e. impacted wisdom tooth).

\section{The role of antibiotics in odontogenic pain}

A Cochrane review recommends that antibiotics are indicated when there is clinical evidence of systemic (e.g. fever or malaise) or local spread of dental infection (e.g. cellulitis, lymphadenopathy or diffused swelling). ${ }^{(21)}$ In such instances, antibiotics with coverage of oral bacteria such as a penicillin with beta-lactamase inhibitor or metronidazole may be prescribed. ${ }^{(22)}$ Antibiotics have a limited role in the treatment of dental infection without spread: the evidence has not shown that antibiotics reduce pain ${ }^{(23)}$ or prevent subsequent dental infections ${ }^{(24)}$ when there is no evidence of spread. Instead, inappropriate use of antibiotics risks resulting in antimicrobial resistance and has adverse effects with minimal benefit to patients. Despite this, the reported rate of antibiotic prescription in primary care patients with odontogenic pain in the United Kingdom has been disproportionately high at $57 \%$. $^{(25)}$

In summary, a safe approach to clinical decision-making in patients presenting with tooth pain entails careful differentiation between odontogenic versus non-odontogenic pain, keeping in mind the possibility of underlying red flags. Management decision-making includes the use of simple analgesics, antibiotics only when clinically indicated, and prompt dental or specialist referral when required.

\section{TAKE HOME MESSAGES}

1. The first step in managing tooth pain is to differentiate between odontogenic and non-odontogenic pain with a detailed history and clinical examination of the oral cavity.

2. Keep in mind red flags that may cause non-odontogenic pain, such as acute coronary syndrome, peritonsillar abscess and temporal arteritis.

3. Management of odontogenic pain includes relief of symptoms and, when required, timely referral to the dentist for assessment, tests and treatment.

4. Analgesia such as paracetamol and NSAIDs (e.g. ibuprofen $400 \mathrm{mg}$ three times daily) is preferred.

5. Antibiotics are only indicated if clinical evidence of local or systemic spread of dental infections is present.

On further assessment, you determined that Mr Tan's pain was odontogenic. There was tenderness on percussion of the upper right first molar, a sharp shooting pain on cold stimulus, and lingering of the pain for almost one minute after the cold was removed, suggesting possible endodontic disease. Without evidence of systemic or local spread of infection, you explained that Mr Tan did not need antibiotics. Instead, you suggested that it would be beneficial to see a dentist for assessment and possible root canal treatment. You added ibuprofen to his prescription and arranged a referral to the dentist for the following day. 
ABSTRACT Tooth pain is a common presentation in primary care, with $32.4 \%$ of Singaporeans experiencing pain from dental caries in their lifetime. Some systemic conditions can have oral presentations, and oral conditions may be associated with chronic disease. A good history and examination is key in delineating odontogenic from non-odontogenic causes of tooth pain. Primary care physicians should accurately diagnose and assess common dental conditions and make appropriate referrals to the dentist. Common non-odontogenic causes of orofacial pain can be mostly managed in primary care, but important diagnoses such as acute coronary syndrome, peritonsillar abscess and temporal arteritis must not be missed. Ibuprofen has been shown to be effacious, safe and cost-effective in managing odontogenic pain. Antibiotics are indicated when there is systemic or local spread of dental infection. Without evidence of spread, antibiotics have not been shown to reduce pain or prevent subsequent dental infections.

Keywords: dental care, facial pain, general practice, primary health care, toothache

\section{REFERENCES}

1. Marcenes W, Kassebaum NJ, Bernabé E, et al. Global burden of oral conditions in 1990-2010: a systematic analysis. J Dent Res 2013; 92:592-7.

2. Epidemiology \& Disease Control Division, Ministry of Health Singapore. Singapore Burden of Disease Study 2010. Available at: https://www.moh.gov. sg/docs/librariesprovider5/resources-statistics/reports/singapore-burden-ofdisease-study-2010-report_v3.pdf. Accessed May 22, 2018.

3. Ryan ME, Carnu O, Kamer A. The influence of diabetes on the periodontal tissues. J Am Dent Assoc 2003; 134:34S-40S.

4. Chan BH, Yee R, Puvanendran R, Ang SB. Medication-related osteonecrosis of the jaw in osteoporotic patients: prevention and management. Singapore Med J 2018; 59:70-5.

5. Lockhart PB, Brennan MT, Thornhill M, et al. Poor oral hygiene as a risk factor for infective endocarditis-related bacteremia. J Ame Dent Assoc. 2009; 140:1238-44.

6. Alpert PT. Oral health: the oral-systemic health connection. Home Health Care Manag 2017; 1:56-9.

7. Blakey GH, White RP Jr, Offenbacher S, et al. Clinical/biological outcomes of treatment for pericoronitis. J Oral Maxillofac Surg 1996; 54:1150-60.

8. Glickman GN, Schweitzer JL. Endodontic Diagnosis. Endodontics: Colleagues for Excellence 2013 [online]. Available at: https://www.aae.org/specialty/ wp-content/uploads/sites/2/2017/07/endodonticdiagnosisfall2013.pdf. Accessed May 22, 2018.

9. Ruggiero SL, Dodson TB, Fantasia J, et al. American Association of Oral and Maxillofacial Surgeons position paper on medication-related osteonecrosis of the jaw--2014 update. J Oral Maxillofac Surg 2014; 72:1938-56.

10. Scrivani SJ, Spierings EL. Classification and differential diagnosis of oral and maxillofacial pain. Oral Maxillofac Surg Clin North Am 2016; 28:233-46.

11. Chi AC, Neville BW, Krayer JW, Gonsalves WC. Oral manifestations of systemic disease. Am Fam Physician 2010; 82:1381-8.

12. Mclsaac WJ, Kellner JD, Aufricht $P$, Vanjaka A, Low DE. Empirical validation of guidelines for the management of pharyngitis in children and adults. JAMA 2004; 291:1587-95.

13. Rosenfeld RM, Piccirillo JF, Chandrasekhar SS, et al. Clinical practice guideline (update): adult sinusitis. Otolaryngol Head Neck Surg 2015; 152(2 Suppl):S1-S39.

14. Headache Classification Committee of the International Headache Society (IHS).The International Classification of Headache Disorders, 3rd edition (beta version). Cephalalgia 2013; 33:629-808.

15. Marmura MJ, Silberstein SD, Schwedt TJ. The acute treatment of migraine in adults: the american headache society evidence assessment of migraine pharmacotherapies. Headache 2015; 55:3-20.

16. Lee VME, Ang LL, Soon DTL, Ong JJY, Loh VWK. The adult patient with headache. Singapore Med J 2018; 59:399-406.

17. Schiffman E, Ohrbach R, Truelove E, et al. Diagnostic criteria for temporomandibular disorders (DC/TMD) for clinical and research applications: recommendations of the International RDC/TMD Consortium Network and Orofacial Pain Special Interest Group. J Oral Facial Pain Headache 2014; 28:6-27.

18. Mujakperuo HR, Watson M, Morrison R, Macfarlane TV. Pharmacological interventions for pain in patients with temporomandibular disorders. Cochrane Database Syst Rev 2010; CD004715.

19. Gronseth G, Cruccu G, Alksne J, et al. Practice parameter: the diagnostic evaluation and treatment of trigeminal neuralgia (an evidence-based review): report of the Quality Standards Subcommittee of the American Academy of Neurology and the European Federation of Neurological Societies. Neurology 2008; 71:1183-90.

20. Pozzi A, Gallelli L. Pain management for dentists: the role of ibuprofen. Ann Stomatol (Roma) 2011; 2(3-4 Suppl):3-24.

21. Cope AL, Chestnutt IG, Wood F, Francis NA. Dental consultations in UK general practice and antibiotic prescribing rates: a retrospective cohort study. $\mathrm{Br} J$ Gen Pract 2016; 66:e329-36.

22. Cope A, Francis N, Wood F, Mann MK, Chestnutt IG. Systemic antibiotics for symptomatic apical periodontitis and acute apical abscess in adults. Cochrane Database Syst Rev 2014; CD010136.

23. Oral and Dental Expert Group. Therapeutic guidelines: oral and dental. In: eTG Version 2. Melbourne: Therapeutic Guidelines Limited, 2012.

24. Runyon MS, Brennan MT, Batts JJ, et al. Efficacy of penicillin for dental pain without overt infection. Acad Emerg Med 2004; 11:1268-71.

25. Agnihotry A, Fedorowicz Z, van Zuuren EJ, Farman AG, Al-Langawi JH. Antibiotic use for irreversible pulpitis. Cochrane Database Syst Rev 2016; 2:CD004969. 


\section{SINGAPORE MEDICAL COUNCIL CATEGORY 3B CME PROGRAMME} (Code SMJ 201905A)

1. Oral disease is prevalent and can affect up to $35 \%$ of the population.

2. Toothache is a common presentation in primary care.

3. Patients with poorly controlled diabetes mellitus are more likely to develop periodontal disease.

4. Oral diseases are only caused by poor oral hygiene.

5. Patients with poor oral hygiene have ten times more risk of bacteraemia from endocarditis.

6. A good pain history is fundamental in delineating causes of tooth pain.

7. All cases of tooth pain must be promptly referred and seen by a dentist.

8. Severe dental caries, if left untreated, will lead to endodontic disease.

9. A diagnosis of pericoronitis should be referred to the dentist for extraction.

10. Severe endodontic disease can lead to Ludwig's angina, necessitating admission for intravenous antibiotics.

11. A case of suspected osteonecrosis of the jaw warrants a medication review.

12. A diagnosis of temporal arteritis needs to be considered if a patient presents with visual deficits, jaw claudication, temporal headache and shoulder stiffness.

13. Odontogenic tooth pain can manifest as non-odontogenic complaints such as headache.

14. Temporomandibular joint dysfunction may be treated conservatively with dental splints.

15. Differentials of trigeminal neuralgia include herpes zoster, multiple sclerosis and even brain tumours.

16. Amitriptyline is the drug of choice for the treatment of trigeminal neuralgia.

17. Ibuprofen is a good choice of analgesia for management of tooth pain.

18. Antibiotics are indicated in the event of systemic or local spread of tooth infection.

19. Antibiotics have been shown to prevent subsequent dental infections.

20. In cases of tooth pain, antibiotics have been shown to reduce the need for analgesia.

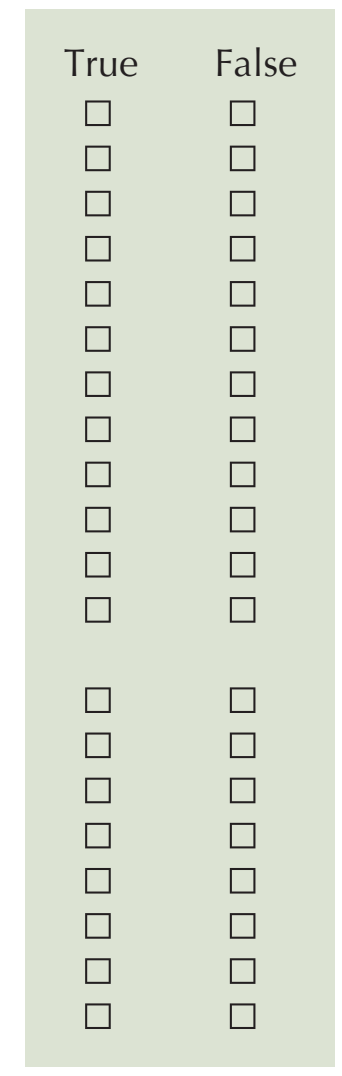

\section{Doctor's particulars:}

Name in full:

MCR no.:

Specialty:

Email:

\section{SUBMISSION INSTRUCTIONS:}

Visit the SMJ website: http://www.smj.org.sg/current-issue and select the appropriate quiz. You will be redirected to the SMA login page.

For SMA member: (1) Log in with your username and password (if you do not know your password, please click on 'Forgot your password?'). (2) Select your answers for each quiz and click 'Submit'.

For non-SMA member: (1) Create an SMJ CME account, or login with your SMJ CME username and password (for returning users). (2) Make payment of SGD 21.40 (inclusive of $7 \%$ GST) via PayPal to access this month's quizzes. (3) Select your answers for each quiz and click 'Submit'.

RESULTS:

(1) Answers will be published online in the SMJ July 2019 issue. (2) The MCR numbers of successful candidates will be posted online at the SMJ website by 10 July 2019. (3) Passing mark is $60 \%$. No mark will be deducted for incorrect answers. (4) The SMJ editorial office will submit the list of successful candidates to the Singapore Medical Council. (5) One CME point is awarded for successful candidates. (6) SMC credits CME points according to the month of publication of the CME article (i.e. points awarded for a quiz published in the December 2018 issue will be credited for the month of December 2018, even if the deadline is in January 2019).

Deadline for submission (May 2019 SMJ 3B CME programme): 12 noon, 3 July 2019. 